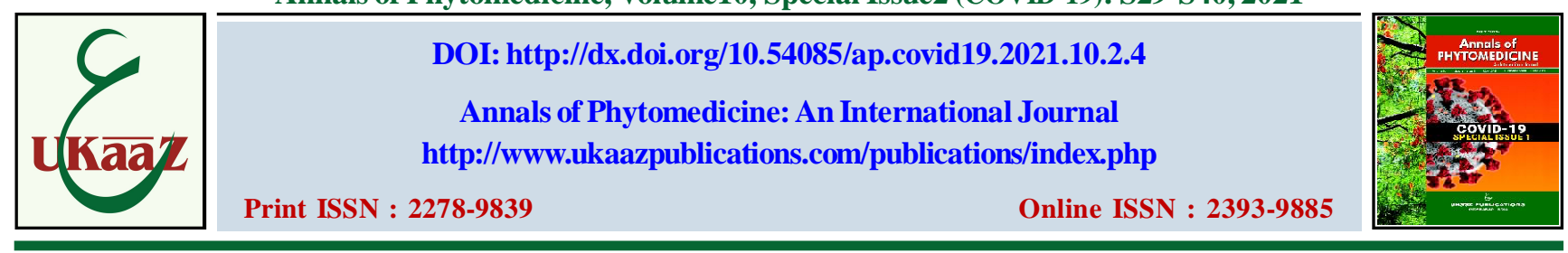

\title{
Potential of algae-derived bioactive molecules for cure of SARS-CoV-2
}

\author{
Afroz Alam*, Fozia Bibi* and Kanishka Porwal \\ Department of Bioscience and Biotechnology, Banasthali Vidyapith, Banasthali-304022, Rajasthan, India \\ *Department of Botany, Rawalpindi Women University, Rawalpindi, Pakistan
}

\section{Article Info}

Article history

Received 12 August 2021

Revised 29 September 2021

Accepted 30 September 2021

Published Online 30 March 2021

Keywords
Algae
antiviral
Pandemic
SARS-CoV-2 virus
Remedies

\begin{abstract}
The exploration for various effective antiviral agents is pressing issue regarding the histrionic circumstances of the global COVID pandemic, a blowout of SARS-CoV-2 virus disease. Actual antiviral remedies are not existing at present and the agreed remedy available for COVID somewhat has not been well recognized yet. In these circumstances, there is a need of more consideration which should be given to the exploration for all possible antiviral agents existing in nature. Though, the algae (marine/fresh water) are one of the richest reservoirs of bioactive complexes yet they are sporadically been studied as antiviral agents. In past, the bioactive compounds of algal origin have demonstrated remarkable in vitro antiviral activity against the HIV and $\mathrm{HCV}$. The present article recapitulates the antiviral possessions of algae or their extracts that have been studied in several in vitro/in vivo animal system-based studies, with the aim that the vast algal diversity should get the due attentions related to the deterrence of SARSCoV-2.
\end{abstract}

\section{Introduction}

Typical construction of viruses and their intricate life cycle have made compulsory to discover effective treatments against them. In spite of various all-inclusive research attempts to determine appropriate immunization approaches against viral infections in recent past, still control of many viruses, viz., human immunodeficiency virus (HIV-AIDS), hepatitis C virus (HCV), papillomavirus and dengue virus (DENV) is an immense challenge in front of scientific community (Buck et al., 2006; Murrell et al., 2011; Loutfy et al., 2013; Lazarus et al., 2014).

The development of vaccine to counter viruses, viz., HIV and HCV was up to now evidenced to be an unfinished task, consequently there is no certain serum available to combat viral infections, such as including herpesviruses (HSV-1 and HSV-2), human papilloma viruses (HPVs) and most respiratory-tract viruses. The elevating resistance in viruses against various drugs available has always been a stern obstruction in the prevention and treatment of such viral infections (Li et al., 2012). However, with improving knowledge base of viral propagation, in its life cycle now, many studies are now noticeable regarding the findings of novel antiviral drugs (De Clercq, 2002). However, regardless of little bit success, still the control on most of the viruses is not attained.

The huge and intricate aquatic bionetwork has given the biosphere of the aquatic system a range of algal diversity from microalgae to oversize algal forms have inspired note worthy financial awareness as, fertilizer, food, agar, source of iodine, and potash, etc. (Yasuhara-

Corresponding author: Dr. Afroz Alam

Associate Professor, Department of Bioscience and Biotechnology, Banasthali Vidyapith, Banasthali-304022, Rajasthan, India

E-mail: afrozalamsafvi@gmail.com

Tel.: +91-9415596994

Copyright $($ ) 2021 Ukaaz Publications. All rights reserved.

Email: ukaaz@yahoo.com; Website: www.ukaazpublications.com
Bell and Lu, 2010). The usefulness of algal forms as food have been known well in ancient times by countless refinement in human beings and their cultural practices worldwide. Then, algal biotechnology has started in the middle of the $20^{\text {th }}$ century which is now developing extensively (Mendes et al., 2003). Especially, the microalgae and blue green algae have given massive forecasts in several industries, such as food, pharmaceuticals and cosmetics because of their potential biosubstances. It has been estimated that around $9 \%$ of biomedical compounds have been derived from various algal forms, especially, marine algae (Jha and Zi-rong, 2004). These marine algal forms can manufacture chlorophyll, amino acids, polysaccharides, fatty acids, acetogenins, vitamins, xanthophylls, and some halogenated compounds during their metabolic activities (Moghadamtousi et al., 2014). Beside these, several studies have showed the significant antiviral possessions in various isolated compounds of algal origin (Mayer and Hamann, 2005) that suggests these algal forms as the influential reservoirs of natural antiviral compounds. Though, algal forms are somewhat underexploited as plant resources, current researches have recognized many algae as a rich cache of bioactive compounds having therapeutic value, including antiviral, antitumor, anticancer and antioxidant properties.

This appraisal recapitulates the antiviral activities biomolecules of algal origin that can be used against the COVID pandemic.

\section{Antiviral biomolecules derived from algae}

\subsection{Polysaccharides}

It was found that polysaccharides obtained from marine algae had inhibitory activity against influenza virus B. The polysaccharides of marine algae origin, especially, the Rhodophyceae forms were then assessed against HIV-1 and HSV (Gerber et al., 1958). Subsequently, several researches have revealed that polysaccharides of algae-driven have antiviral properties (Table 1). Likewise, marine 
microalgal forms, viz., Cochlodidium polykrikoides (Figure 1c) and Porphyridium sp. (Figure 1a) were found to have sulphated exopolysaccharides which had the capability to interact with the enveloped viruses, viz., HIV and HSV, averting them to infect the host cells (Amaro et al., 2011) and also showed worthy antiviral action against HSV (type 1 and 2) in vitro and in vivo in animal system (Huleihel et al., 2001). The antiviral possessions of the polysaccharides obtained from Porphyridium sp. was noted which was due to the adjoining add-on of HSV-1 particles to this polysaccharide (Batiniæ and Robey, 1992). A diatom, Navicula sp. (Figure 1b), is another example from which an extracellular sulphated polysaccharide naviculan was produced. This sulphated polysaccharide contains rhamnose, xylose, galactose, fucose, sulfate, and mannose that were stated to have antiviral consequence on HSV. Naviculan was found to hinders the influenza virus particles from entering the host cells at the early stages of infection (Lee $e t$ al., 2010). Blue green algae also contain vigorous antiviral compounds, for instance, Arthrospira platensis (Figure 2c) consists of exopolysaccharides which showed antiviral activity against koi herpes virus (KHV) (Reichert et al., 2017). The extract of Spirulina platensis (Figure 2d) is identified to have calcium spirulan (Ca-SP), a form of sulphated polysaccharide. This Ca-SP contains ribose, galactose, mannose, fructose, and rhamnose which are known to interrupt the replication process of both enveloped (Influenza A, HIV) and non-enveloped (polio, HSV) forms of viruses (Takebe et al., 2013).
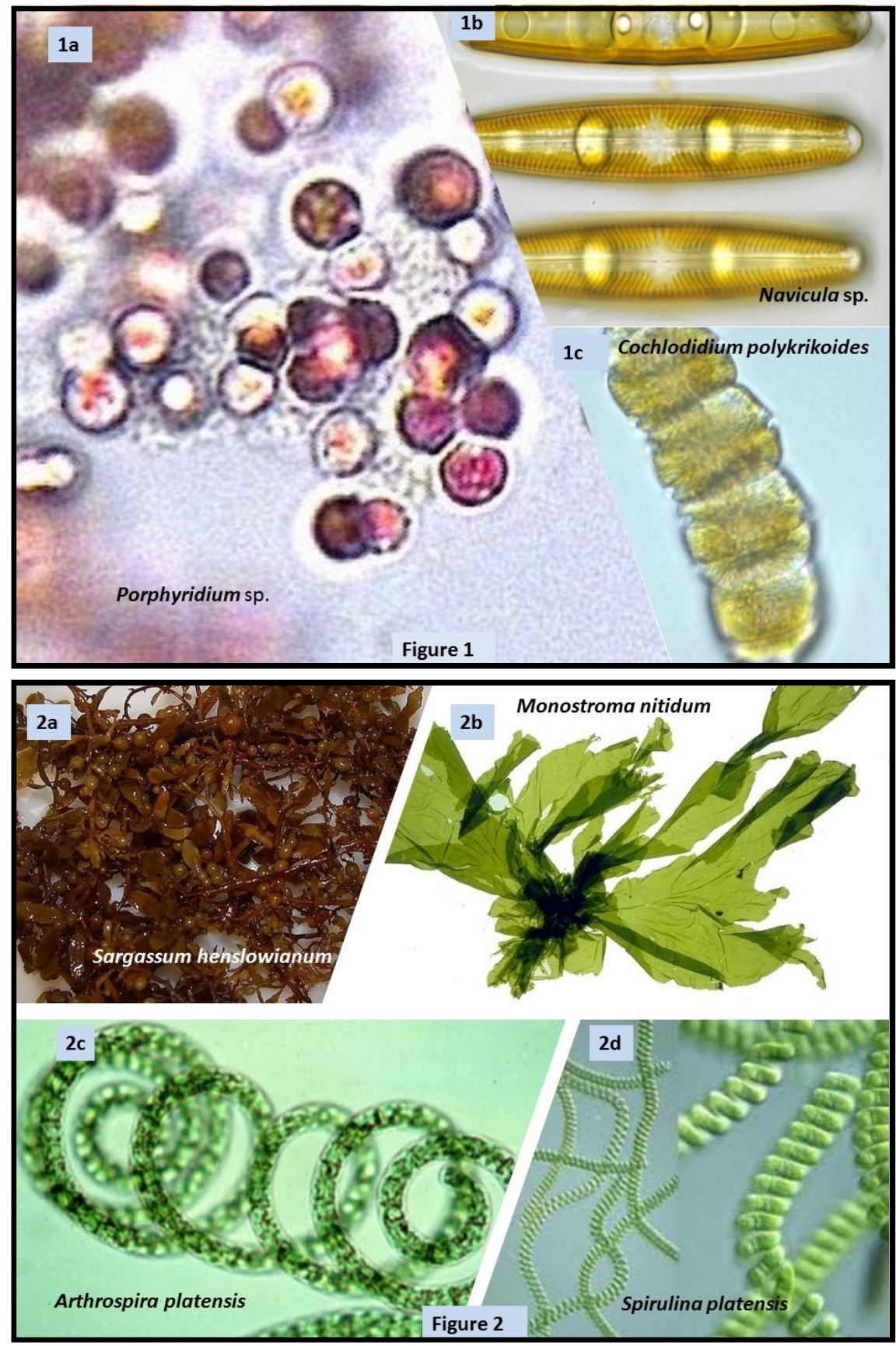
According to several crude in vitro/in vivo experiments, it has been demonstrated that sulphated polysaccharides of algal origin can activate both the cellular and/or humoral responses to strengthen the immunity (de Paniagua-Michel et al., 2014). Recently, to fucoidans from brown algae (Sargassum henslowianum; Figure 2d) have been purified and characterized and designated as SHAP-1 and SHAP-2, both showed considerable antagonistic activity against the HSV-1 and HSV-2 strains of herpes simplex virus (Sun et al., 2019). Their $\mathrm{IC}_{50}$ value was estimated around 0.89 (SHAP-1) and $0.82 \mu \mathrm{g} \mathrm{ml}^{-1}$ (SHAP-2) to counter HSV-1 strain (Sun et al., 2019). However, in case of HSV-2, the $\mathrm{IC}_{50}$ values were reported low $(0.48$ $\mu \mathrm{g} \mathrm{ml}^{-1}$ ). Correspondingly, time-based experiments discovered the more effective anti-HSV activities were attained when fucoidans (Figure 8e) were supplemented in the contagion phase, thus portentous their utility at the initial phases of viral contamination. Moreover, the adsorption and infiltration assays verified the involvement of fucoidans in disruptionof HSV binding to the host cell. Therefore, fucoidans have potential to inhibit the initial adsorption stage of HSV-2 viruses and proved its clinical claims. Similarly, a green macroalgae Monostroma nitidum (Figure 2b) also produces a sulphated polysaccharide which was isolated and acknowledged as sulphated glucuronorhamnan (water-soluble) named as MWS (Wang et al., 2020). This MWS exhibited broadspectrum antiviral activity and found effective in vitro against a strain of human pathogenic enterovirus (EV71). It was pragmatic that MWS was not lethal to the experimental animal cell lines and confirmed as a broad-spectrum antiviral agent, particularly against EV71 under well-defined in vitro conditions. It was reported that MWS hinders the contagion of EV71.

Likewise, the SPs attained from algal species like Ulva clathrata (Figure 3b) and Cladosiphon okamuranus (Figure 3d) were showed noteworthy in vitro antiviral activity in case of new castle virus (Aguilar-Briseño et al., 2015). Other algae, viz., Sargassum sp. (Figure 2a; 3c), Ulva pertusa, Grateloupia filicina (Figure 3a) also reported as the potential source of SPs that are effective in vivo and in vitro conditions against the avian influenza virus (Kwon et al., 2017).

Curiously, recently the potential of SPs obtained from red alga (Porphyridium sp.) reported as a possible healing agent to fight the COVID-19 (Ramakanth et al., 2021). Since, the SPs of Porphyridium sp. were found effective against a range of viruses, viz., varicella zoster virus (Huleihel et al., 2001; Chelsea et al., 2020), vaccinia virus hepatitis B virus (Schillie et al., 2018), HSV (Huheihel et al., 2002), and retroviruses (Zheng et al., 2020). Hence, this red alga holds enormously promising in the progress to manufacture an immunizing composition against SARS-CoV-2 too. Paul et al. (2020) also reported the active inhibition of SARS-CoV-2 by fucoidans found in Saccharina japonica (Figure 4c) during in vitro study. The SPs were found highly branched and categorized as RPI-27 and RPI-28 and found inhibitory to SARS-CoV-2 by interfering with the binding ability of viral S protein. Further, the RPI-27 was found better in comparison to the popular anti-COVID drug remdesivir.

Thus, the examples suggest the prospect of employing algal components either alone or in blend with other antiviral agents as a hopeful healing approach against the infection of SARS-CoV-2 (Paul et al., 2020).

\subsection{Proteins}

Various species of algae are known to produce antiviral proteins. Lectins are the most common of them which are basically carbohydrate-binding proteins (glycoproteins). These proteins can confer with carbohydrates and carbohydrate moieties of the glycoconjugates. In the recent past, diverse lectins that have antiHIV action by conferring sturdily with moieties of carbohydrate on the glycosylated envelope of HIV have been identified (Huskens and Schols, 2012) (Table 2).

The envelope of HIV displays anessential mannose-rich glycoprotein (gp120) on its surface to bind to facilitate the binding to the cellular receptor CD4 of the target cells (Tiwari et al., 2009). Further, Scenedesmus obliquus (Figure 4b) hydrolysates, viz., Sd, $\mathrm{Sd} 1$ and $\mathrm{Sd} 2$ possess a sturdy antiviral activity against Coxsackie virus B (Afify et al., 2018).

\subsubsection{Potential of lectins}

Macroalgae have plenty of carbohydrate-binding proteins, e.g., lectins, which have high specificity towards the sugar groups of viral glycoproteins. Therefore, lectins have become widely used in numerous pharmacological and remedial applications (Breitenbach Barroso Coelho et al., 2018). In various viral infection pathways, the Mannose-binding lectins (MBL) are the majorly studied protein (Auriti et al., 2017) and it was reported that the self-organization of viruses during their replication cycle is interrupted by MBL (Gupta and Gupta, 2021). Later, these proteins have also been shown to be a possible therapy against Ebola virus (Michelow et al., 2011).

Lectins derived from red algae were first highlighted when Griffithsin was revealed by Watson and Waaland (1983) in Griffithsia sp. (Figure 4a). Consequently, it has been studied extensively for various uses (Mori et al., 2004). As antiviral agent it has been found to have high specificity for mannose residues present in viral glycoproteins and remarkable antiviral potential was reported in case of HIV1 (Lusvarghi et al., 2016), hepatitis C (Meuleman et al., 2011) and the SARS-CoV glycoprotein (Zumla et al., 2016). Recently, the antiMERS CoV activity of Griffithsin was also reported, where the lectins inhibited virus invasion while conferring insignificant cellular noxiousness. The curbing consequence of Griffithsin on the binding stage during virus contamination was also investigated (Millet et al., 2016).

Furthermore, several other similar attempts have demonstrated the in vivo antiviral activity of this Griffiths into counter the replication of Herpes simplex virus 2 (Nixon et al., 2013), Japanese encephalitis virus (Ishag et al., 2013), and human papilloma virus (Levendosky et al., 2015). For example, the effect of an anti-HIV Griffithsincontaining microbicide on the rectal microbiome in Rhesus macaques (Girard et al., 2018). It was observed that the $0.1 \%$ Griffiths in gel had no adverse effects on the proteome or microbiome of the rectal mucosa. Earlier, O' Keefe et al. (2010) testified 100 per cent survival of model mice infected with a high dose of SARS-CoV-2 when a 10 dose of Griffithsin was administered. 


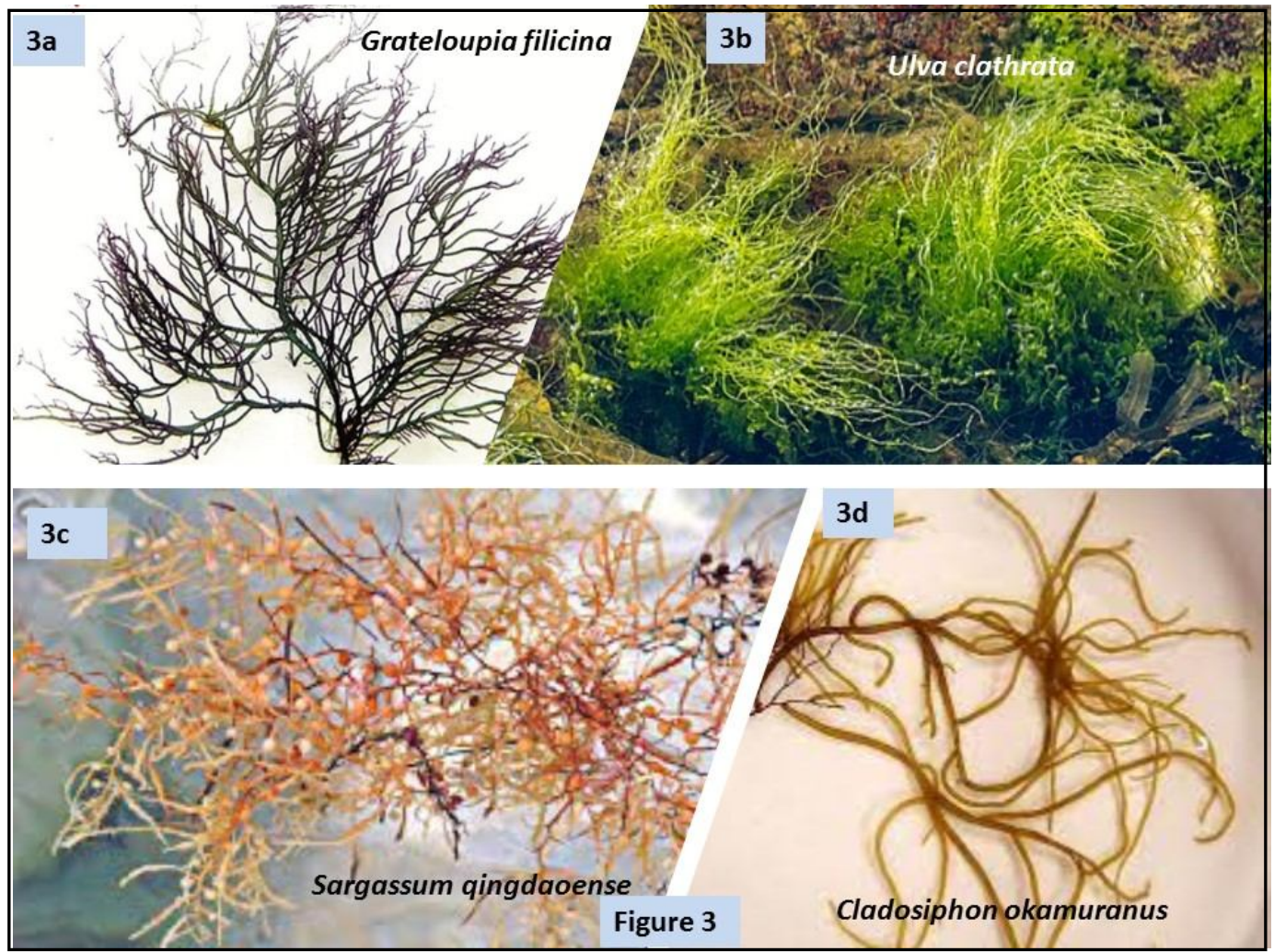

Table 1: Algal proteins with antiviral properties (Ahmadi et al., 2015)

\begin{tabular}{|c|c|c|}
\hline Algal group & Antiviral proteins and source species & Target viruses \\
\hline \multirow[t]{3}{*}{ Red algae } & $\begin{array}{l}\text { Carrageenan }\left(\mathrm{C}_{23} \mathrm{H}_{23} \mathrm{FN}_{4} \mathrm{O}_{7} \mathrm{Zn}\right) \text { (Gigartina skottsbergii; } \\
\text { Figures 5a; 8d) }\end{array}$ & $\begin{array}{l}\text { Influenza virus, DENV, HSV-1, HSV-2, } \\
\text { HPV, HRV, HIV }\end{array}$ \\
\hline & $\begin{array}{l}\text { Galactan }\left(\mathrm{C}_{6} \mathrm{H}_{10} \mathrm{O}_{5}\right) \mathrm{n} \text { (Callophyllis variegata; } \\
\text { Figures } 5 \mathrm{c} ; 8 \mathrm{~b})\end{array}$ & HSV-1, HSV-2, HIV-1, HIV-2, DENV, HAV \\
\hline & Sea algae extract (Schizymenia pacifica; Figure 5c) & HIV, AMV, RMLV \\
\hline \multirow[t]{4}{*}{ Brown algae } & $\begin{array}{l}\text { Alginate }\left(\mathrm{C}_{6} \mathrm{H}_{8} \mathrm{O}_{6}\right) \mathrm{n} \text { (Figure 8f) (Laminaria spp.; } \\
\text { Figure } 6 \mathrm{a} \text { ) }\end{array}$ & HIV, IAV, HBV \\
\hline & Sulfated polymannuroguluronate (Ulva sp.; Figure 8a) & HIV \\
\hline & Fucan $\left(\mathrm{C}_{6} \mathrm{H}_{9} \mathrm{O}_{3} \mathrm{SO}_{3}\right) \mathrm{n}$ (Adenocytis utricularis; Figure $6 \mathrm{~b}$ ) & HSV-1, HSV-2, HCMV, VSV, Sindbis virus, HIV-1 \\
\hline & Laminaran $\left(\mathrm{C}_{6} \mathrm{H}_{10} \mathrm{O}_{5}\right) \mathrm{x}$ (Fucus vesiculosus; Figures $6 \mathrm{c} ; 8 \mathrm{c}$ ) & HIV \\
\hline Diatom & Naviculan (Navicula directa) (Figure $1 \mathrm{~b}$ ) & HSV-1, HSV-2 \\
\hline Microalga & A1 and A2 (Cochlodidium polykrikoides; Figure 1c) & $\begin{array}{l}\text { Influenza A and B viruses, RSV-A, RSV-B, } \\
\text { parainfluenza-2 }\end{array}$ \\
\hline Blue-green alga & Calcium spirulan (Arthrospira platensis; Fig.2c) & $\begin{array}{l}\text { HSV-1, measles, mumps, influenza, polio, } \\
\text { Coxsackie, HIV-1, HCMV }\end{array}$ \\
\hline Blue-green alga & Nostaflan (Nostoc flagelliforme) & $\begin{array}{l}\text { HSV-1, HSV-2, influenza A virus, human } \\
\text { cytomegalovirus }\end{array}$ \\
\hline
\end{tabular}

\subsection{Lipids}

Though, the lipids derived from algae lesser antiviral activity compared to algal polysaccharides and proteins yet the lipid compounds (sulfolipids and glycolipids) such as sulfo-quinovosyldiacyl-glycerol (SQDG) and mono-galactosyl-diacyl-glycerides
(MGDG) exhibited antiviral potential. Gustafson et al. (1989) noticed the anti-HIV activity in SQDG which was isolated from Phormidium tenue and Lyngby alagerheimii. Spirulina's methanol extract $\left(\mathrm{IC}_{50}\right.$ value of $25.1 \mathrm{~g} \mathrm{ml}^{-1}$ ) was also reported to have antiviral activity against HIV-1 (Zalah et al., 2002; Yim et al., 2004; Li et al., 2008) (Table 2). 


\subsection{Pigments}

There is a huge diversity in algal pigments and these algal pigments also showed appreciable bioactivity against viruses. For instance, photosynthetic pigments of Dunaliella primolecta have confirmed anti-HSV activity (Ohta et al., 1998). Likewise, a diatom (Haslea ostrearia) which produces a water-soluble fraction (blue pigment) containing marennine $\left(\mathrm{IC}_{50}\right.$ value: $4 \mu \mathrm{g} \mathrm{ml}^{-1}$ ), was reported to constrain HSV-1 replication in vitro. Moreover, this component extended the progress of syncytia caused by HIV-1 in MT2 cells (Kamat et al., 1992; Shih et al., 2003). Cyanophycean and red algae contain phycobiliproteins as their key photosynthetic pigments that have pharmaceutical importance as the natural coloring agent. The two most acknowledged phycobiliproteins are phycoerythrin and phycocyanin have been isolated from Arthrospira and Porphyridium, respectively, supposed to have antiviral potential and can be used in future as antiviral agents (Table 2).

Phycocyanobilins (PCBs) found in some cyanobacteria and red algae as light-capturing pigments are also extensively investigated in the recent past for their antioxidant, antiviral and inhibitory NADPH oxidase activities (Hirata et al., 2000; McCarty, 2007; Ramakrishnan, 2013; Guedes et al., 2019). Recently, regarding their antiviral role, Pendyala and Patras (2020) conferred the probable use of phycocyanobilins of Spirulina spp. as potential inhibitors of SARS-CoV2 contagion by affecting its binding ability to the host cell. The base of this was an in silico study (via COVID-19 docking server) of these bioactive compounds found in Spirulina spp.

Remarkably, the PCB verified a better binding to targeted enzymes the well-known antiviral drugs such as remdesivir, lopinavir and nelfinavir. Thus, the finding emphasized, the noteworthy probable of PCB as antiviral agent. Moreover, the cleansed allophycocyanin attained from Spirulina platensis (Figure 2d) has been confirmed substantial inhibitory activity against enterovirus 71 (Singh et al., 2020). Similarly, outcomes of an in silico study established that the PCB found in Arthrospira sp. could be used as an effective antiviral against SARS-CoV-2 (Petit et al., 2020). Recently, it was reported by Nikhra (2020) the likelihood to employ phycocyanobilin holding cyanobacteria (Spirulina sp.) to control the infections of RNA viruses.

The extract of PCB proved a considerable decline in the existence of zoonotic RNA viruses by elevating the host immune responsive type 1 interferon (Nikhra, 2020). Henceforth, it is expected that $\mathrm{PCB}$ of microalgal origin may reveal significant action in contradiction of SARS-CoV-2 (Zhou et al., 2020; Cascella et al., 2020). However, there is an acute need of further research regarding in vivo studies to recognize the specificity of $\mathrm{PCBs}$ for the progress in therapeutic approaches to counter the human pathogenic viruses, together with SARS-CoV-2.

\section{Antiviral properties of algae}

Immunization is the most effective method against the viral ailments, but some viruses are some what unaffected during immunization; for instance, immunization against active herpetic infections were found unaffected (Naesens and Clercq, 2001), and it was found to generate side effects like allergic responses due to resistance mutation in virus in case of the long-term conduct. Some algal extracts were tested for their antiviral effects on different viruses, including herpes (Serkedjieva, 2004) that showed the effectiveness of brown algae as antiviral agents.

Many brown algae have also been evaluated for their antiviral potential and rousing results have been obtained but the immunosuppressive nature of these compound is a major concern to finalize their roles as antiviral agents (Munro et al., 1987).

Table 2: Algal protein, lipids and pigments with antiviral properties (Intan et al., 2018)

\begin{tabular}{|c|c|c|}
\hline Algal group & Antiviral lectins and source species & Target viruses \\
\hline \multirow[t]{2}{*}{ Cyanobacteria } & $\begin{array}{l}\text { cyanovirin-N (Nostoc ellipsosporum; Figure 7e) } \\
\text { scytovirin (Scytonema varium; Figure 7c) } \\
\text { cyanovirin-N (Nostoc ellipsosporum) } \\
\text { Agglutinin (Oscillatoria agardhii; Figure 7a) }\end{array}$ & HIV \\
\hline & Antiviral lipids and source species & \\
\hline \multirow[t]{2}{*}{ Cyanobacteria } & $\begin{array}{l}\text { sulfoquinovosyldiacylglycerides (SQDG) } \\
\text { [Spirulina spp., Lyngbya lagerheimii (Figure 7b) } \\
\text { and Phormidium tenue] } \\
\text { monogalactosyl-diacylglycerides (MGDG), galactosyl } \\
\text { diacylglycerides (DGDG) (Phormidium tenue) }\end{array}$ & HIV \\
\hline & Antiviral pigments and source species & \\
\hline Cyanobacteria & $\begin{array}{l}\text { chlorophyll analogues (pheophorbide-like substances)(Geitlerinema sp.; Figure 7d) } \\
\text { Marennine, the blue pigment (Haslea ostrearia) } \\
\text { Phycocyanin (Arthrospira sp.) and phycoerythrin (Porphyridium sp.) } \\
\text { allophyco-cyanin [Spirulina (Arthrospira) platensis] }\end{array}$ & $\begin{array}{l}\text { HSV } \\
\text { HSV-1 } \\
\text { HSV } \\
\text { Enterovirus } 71\end{array}$ \\
\hline
\end{tabular}



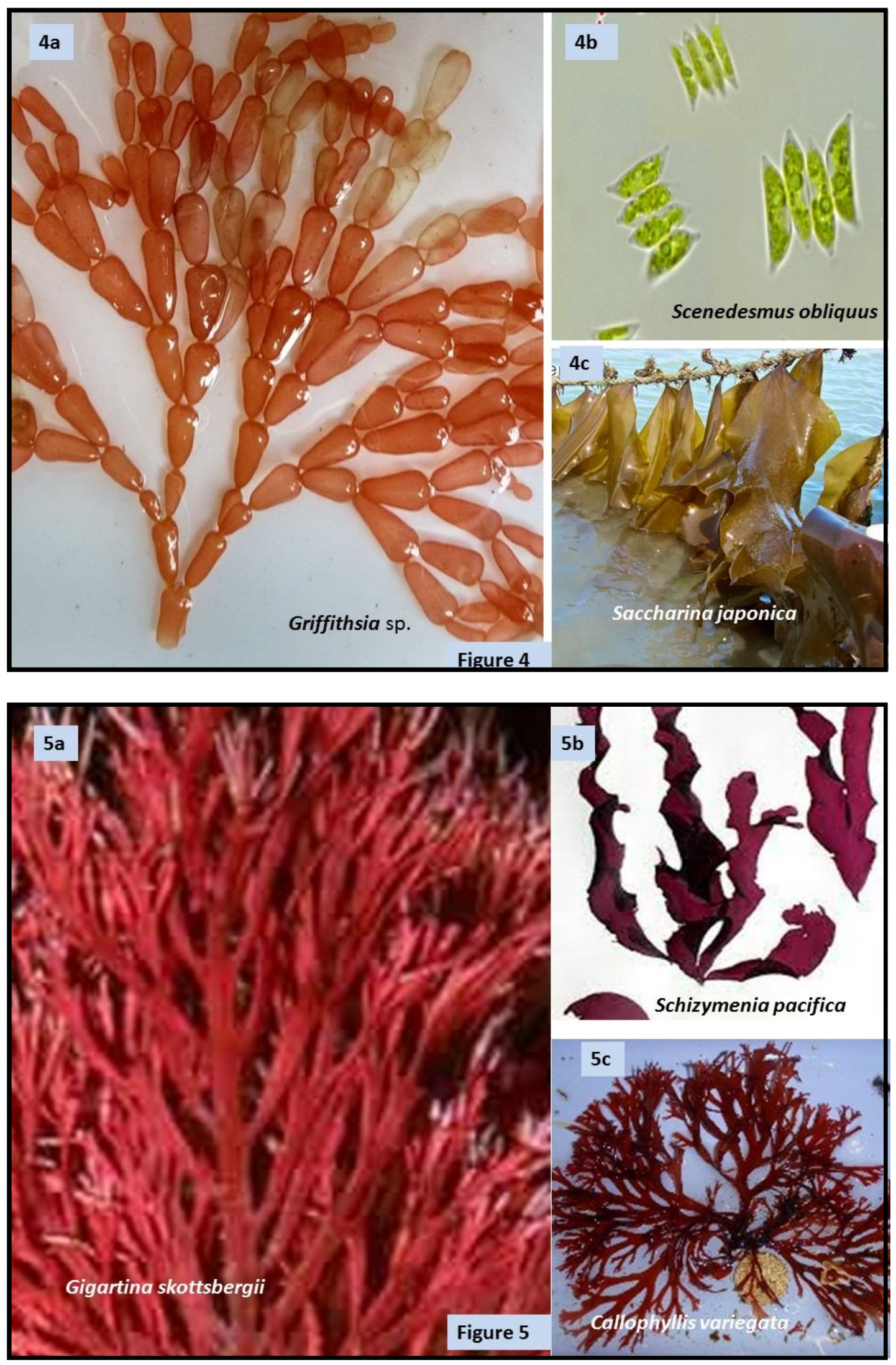

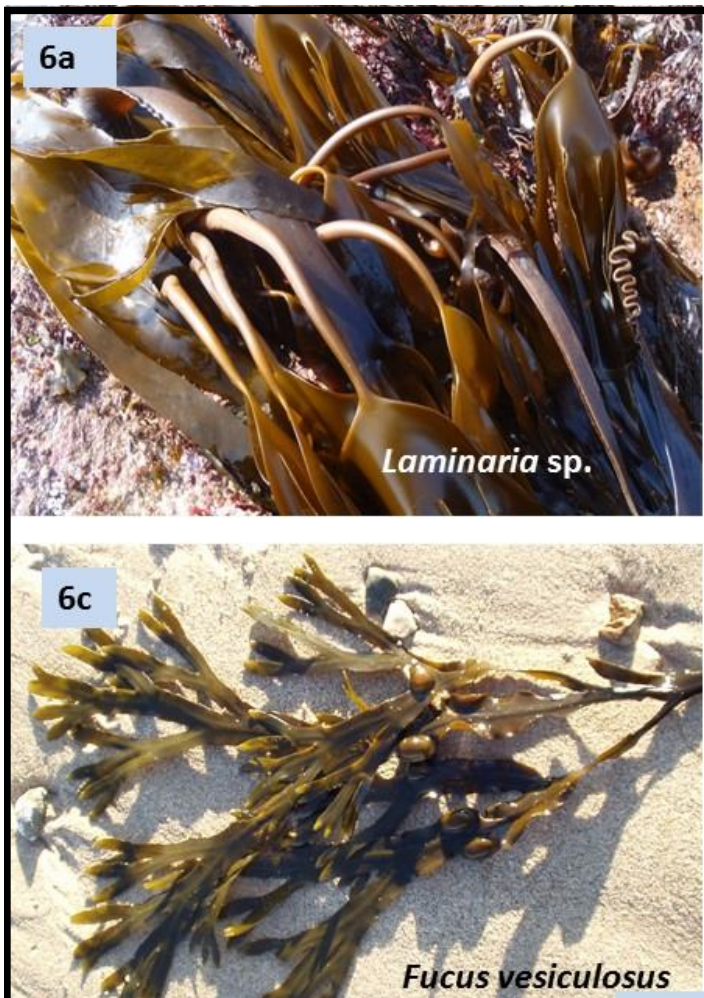

Figure 6
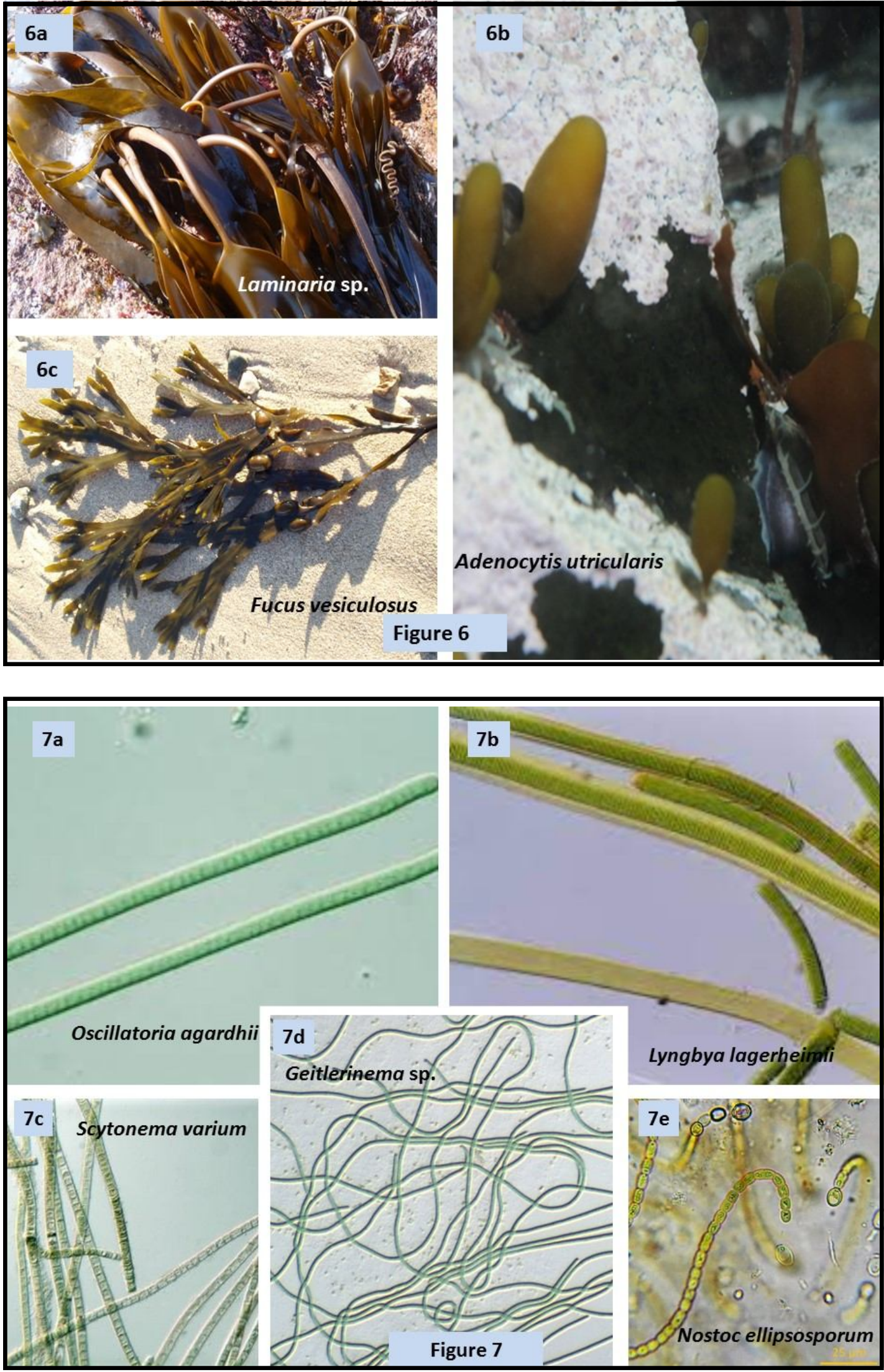


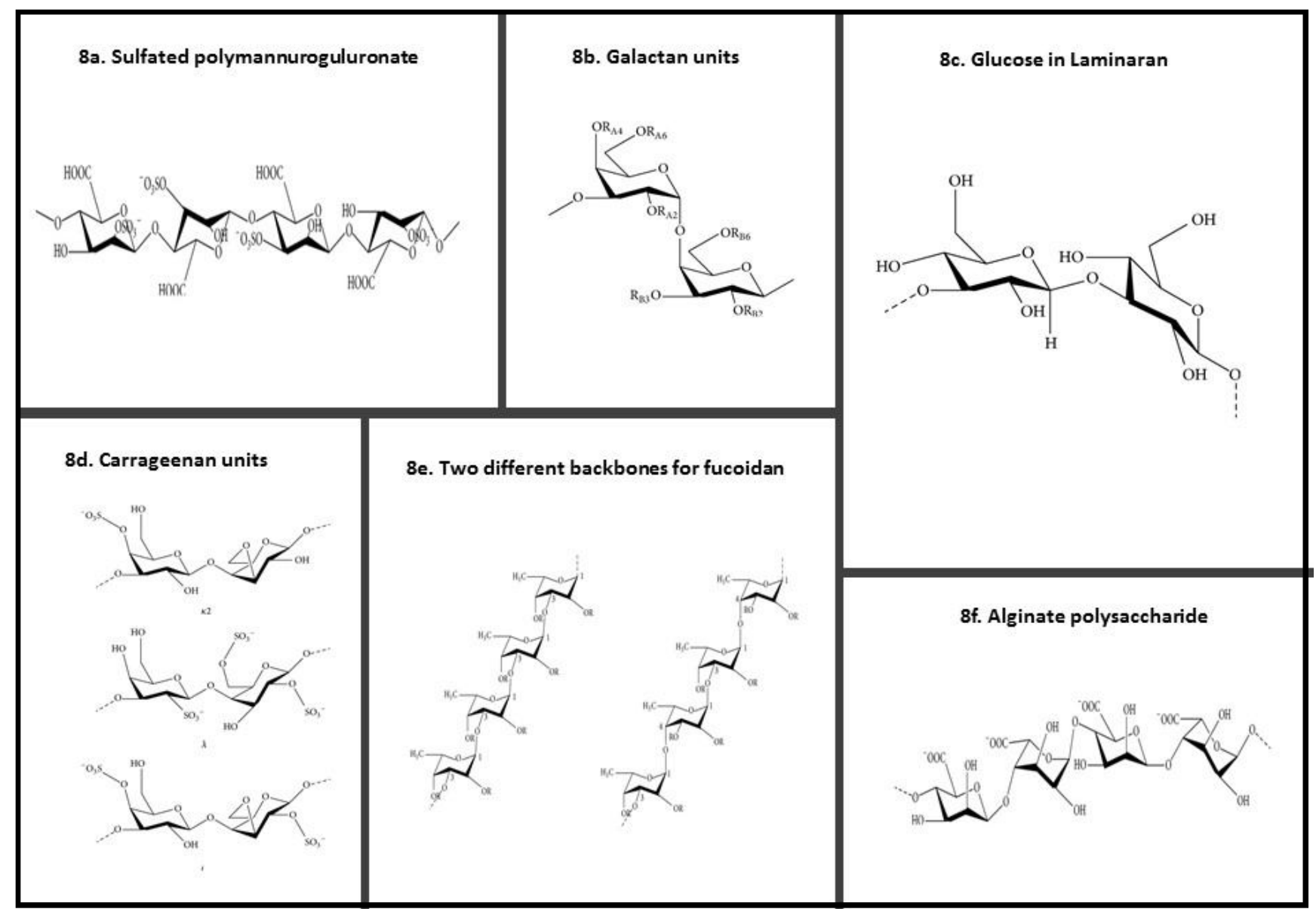

Figures 8a-8f: Chemical structures of algal derived significant compounds of antiviral nature (Ahmadi et al., 2015).

\subsection{Use of algae against SARS-CoV-2 virus}

Considering the alarming situation of the continued COVID-19 pandemic, more and more efforts are required to develop and formulate green remedy alternatives in the form of easily available algal resources to address viral diseases. The SARS-CoV-2, a positive single strand RNA virus from beta corona virus family contains diverse spike proteins along with non-structural (3-chymotrypsinlike protease, helicase, papain-like protease, and RNA-based RNA polymerase), and other proteins (Yeo et al., 2020; Li and De Clercq, 2020). Among all components of this virus, especially, the spike glycoprotein has been taken into consideration, as it plays the decisive role in infection by reacting with the host's receptors ( $\mathrm{Li}$ and $\mathrm{De}$ Clercq, 2020). Since, the glycoprotein is essential for the access of virus into the host cells, therefore, numerous current researches are targeted in this structural protein to combat the viral infection (Zumla et al., 2016).

Based on past researchers, it is obvious that till date the use of algal diversity for their biologically active compounds are basically restricted to HIV and HSV, however, the antiviral action is appreciable in case of these viruses. Since, the biologically active compound obtained from various algae have shown good antagonist activity in the binding of enveloped viruses to the host cell, and to slow down the replication of virus genome in the affected cells of the host.
Both these properties of algal compounds are encouraging to use these algae against the tarnished SARS-CoV-2 virus.

\section{Discussion}

Hitherto, algal forms represent a huge reservoir of antiviral compounds where the novel antiviral compounds can be found after serious explorations. Thus, there is a great need of unceasing research determination to get new algal derived bioactive compounds. Microalgal and cyanobacterial forms can serve the humanity by producing pharmaceutically useful and low-cost manufacture systems to generate natural vaccines, particularly for developing countries. As evident in the well-known genetic transformation attempt in Chlamydomonas reinhardtii which permitted the making of antigens against malaria and cholera (Jones et al., 2012; Gregory et al., 2013). The biosynthesis of silver nanoparticles (AgNPs) by microalgae or Cyanophyta could epitomize a new arena of research (Merin et al., 2010), if the nanotechnologies will able to validate the nonappearance of risks related with the well-being and ecological impacts.

Several biological activities, together with the unique antiviral effect, have been recognized from different algae akin to angiosperms (Mehrotra, 2020) and bryophytes (Alam, 2021). The extracted molecules from diverse algal species have evidently proved this potential of various algae. Though, the findings are mainly restricted to in vitro experiments, yet attempts are being made in vivo. Several 
studies have been done in recent past to elucidate and promote the use of algal diversity in the pharmaceutical industry, especially as effective antiviral agents. Hence, there is a great scope and opportunities to the researchers to explore this aspect of both fresh water and marine algae. The marine algae are categorically varied, high yielding, bioactive, and chemically distinctive leads a great hope for discovering new anticancer drugs. The seaweeds contain polyphenols and sulphated polysaccharides are rich in the clinically effective chemical component. Since algae proved to be the imperative source of vitamins, antioxidants, minerals and natural dyes, the combination of the whole biomass in food and feed could be used to provide color, enhance dietary value and increase texture or confrontation to the oxidation process. While a combination of various species of seaweeds or incorporation with other traditional food opens many likelihoods.

\section{Conclusion}

There has been a significant upsurge that discloses the antiviral activity of several algal metabolites like sulphated polysaccharides, lectins and phycocyanobilins. In the recent past, it has been reported that these algal-derived compounds confer significant action to counter a varied range of RNA and DNA viruses, including the influenza virus, the potential cause of respiratory infections. As conferred, the bioactive molecules of algal origin could assist in the formulations a novel therapy to block the spread and impact of SARS-CoV-2. Considering the acute necessity for the development of formulations against SARS-CoV-2. The available diversity and essential farming of selective algal colonies with plenty of medicinal values needs to be explored and improved by the latest technology to combat SARS-CoV-2 virus disease.

\section{Acknowledgements}

The authors would like to express their gratitude to Professor Ina Shastri, Vice-Chancellor, Banasthali Vidyapith, Rajasthan for her encouragement and assistance. AA and KP also thank DST for providing networking support through the FIST program at the Department of Bioscience and Biotechnology, Banasthali Vidyapith as well as the Bioinformatics Center, Banasthali Vidyapith, funded by DBT.

\section{Authors' contribution}

AA conceptualized the review topic and finalized the manuscript. FB and KP collected the relevant material and prepared the first draft. All the authors have finally read the manuscript and approved.

\section{Conflict of interest}

The authors declare no conflicts of interest relevant to this article.

\section{References}

Afify, A.; El Baroty, G.; El Baz, F.; Abd El Baky, H. and Murad, S. (2018) Scenedesmus obliquus: Antioxidant and antiviral activity of proteins hydrolyzed by three enzymes. Journal of Genetic Engineering and Biotechnology, 16(2):399-408.

Aguilar-Briseño, J.A.; Cruz-Suarez, L.E.; Sassi, J.F.; Ricque-Marie, D.; ZapataBenavides, P.; Mendoza-Gamboa, E.; Rodríguez-Padilla, C. and Trejo-Avila, LM. (2015). Sulphated polysaccharides from Ulva clathrata and Cladosiphon okamuranus seaweeds both inhibit viral attachment/ entry and cell-cell fusion, in NDV infection. Marine Drugs, 13(2):697-712. doi: $10.3390 / \mathrm{md} 13020697$
Ahmadi, A.; Moghadamtousi, Z.S.; Abubakar, S. and Zandi, K. (2015). Antiviral potential of algae polysaccharides isolated from Marine sources: A review. Bio. Med. Research International, 15:1-10. https:// doi.org/10.1155/2015/825203.

Alam, A. (2021). Potential of bryophytes in prevention and medication of COVID-19. Ann Phytomed, 10[Special Issue1 (COVID-19)]: S121-S129. http://dx.doi.org/10.21276/Citation ap.2021.10.1.12

Amaro, H.M..; Catarina Guedes, A. and Xavier Malcata, F. (2011). Antimicrobial activities of microalgae: An invited review. In: A. Méndez-Vilas (Ed.) Science against microbial pathogens: Communicating current research and technological advances. World Scientific Publishing Co. Pvt. Ltd. Singapore.

Auriti, C.; Prencipe, G.; Moriondo, M.; Bersani, I.; Bertaina, C.; Mondì, V. and Inglese, R. (2017). Mannose-binding lectin: Biologic characteristics and role in the susceptibility to infections and ischemia-reperfusion related injury in critically Ill neonates. Journal of Immunological Research, 17:7045630. doi:10.1155/2017/7045 630 .

Batinić, D. and Robey, F. (1992). The V3 region of the envelope glycoprotein of human immunodeficiency virus type 1 binds sulfated polysaccharides and CD4-derived synthetic peptides. Journal of Biological Chemistry, 267(10):6664-6671.

Breitenbach Barroso Coelho, L.; Marcelino dos Santos Silva, P.; Felix de Oliveira, W.; de Moura, M.; Viana Pontual, E.; Soares Gomes, F.; Guedes Paiva, P.; Napoleão, T. and dos Santos Correia, M. (2018). Lectins as antimicrobial agents. Journal of Applied Microbiology, 125:1238-1252. https:/ /doi.org/10.1111/jam.14055

Buck, C.; Thompson, C.; Roberts, J.; Müller, M.; Lowy, D. and Schiller, J. (2006). Carrageenan is a potent inhibitor of papillomavirus infection. PLoS pathogens, 2(7):69.

Cascella, M.; Rajnik, M.; Cuomo, A.; Dulebohn, S.C. and Di Napoli, R. (2020). Features, evaluation and treatment coronavirus (COVID-19). Florida: Stat Pearls Publishing.

Chelsea, G.; Tessa M, Campbell.; Jarrod J., Kennedy.; Brian P, McSharry.; Megan, S.; Barry S. and Allison, A. (2020). Manipulation of the innate immune response by varicella zoster virus. Frontiers in immumology, doi: 10.3389/fimmu.2020.00001

Claudia, V.; Arthur, R.; Aaron, H.; Penina, H.; John, W. Ward.; Noele, P. and Nelson. (2018). Prevention of hepatitis B virus infection in the United States: Recommendations of the Advisory Committee on Immunization Practices. MMWR Recommendations and Reports, 67(RR-1):1-31. http://dx.doi.org/10.15585/mmwr.rr6701 a 1

De Clercq, E. (2002). "Strategies in the design of antiviral drugs," Nature Reviews Drug Discovery, 1(1):13-25.

Gaikwad, M.; Pawar, Y.; Nagle, V. and Dasgupta, S. (2020). Marine red alga Porphyridium sp. as a source of sulfated polysaccharides (SPs) for combating against COVID-19. Available online at: www.preprints. org.

Gerber, P.; Dutcher, J.; Adams, E. and Sherman, J. (1958). Protective effect of seaweed extracts for chicken embryos infected with influenza B or mumps virus. Experimental Biology and Medicine, 99(3): 590593.

Girard, L.; Birse, K.; Holm, J.; Gajer, P.; Humphrys, M.; Garber, D.; Guenthner, P.; Romas, L.; Abou, M.; Mccorrister, S.; Westmacott, G.; Wang, L.;Rohan, L.; Matoba, N.; McNicholl, J.; Palmer, K.; Ravel, J. and Burgener, A. (2018). 
Impact of the griffithsin anti-HIV microbicide and placebo gels on the rectal mucosal proteome and microbiome in non-human primates. Scientific Reports. 8. 10.1038/s41598-018-26313-8.

Gregory, J.A.; Topol, A.B.; Doerner, D.Z. and Mayfield, S. (2013). Alga-produced cholera Toxin-Pfs 25 fusion proteins as oral vaccines. Applied and Environmental Microbiology, 79:3917-3925.

Guedes, A.C.; Amaro, H.M.; Sousa-Pinto, I. and Malcata, F.X. (2019). "Algal spent biomass-A pool of applications," in biofuels from Algae, eds A. Pandey, J.-S. Chang, C. R. Soccol, D.-J. Lee, and Y. Chisti (Porto: Elsevier;), pp:397-433.

Gupta, A. and Gupta, G.S. (2021). Status of mannose-binding lectin (MBL) and complement system in COVID-19 patients and therapeutic applications of antiviral plant MBLs. Molecular and Cellular Biochemistry, 476:2917-2942. doi.org/10.1007/s11010-02104107-3

Gustafson, K.; Cardellina, J.; Fuller, R.; Weislow, O.; Kiser, R.; Snader, K.; Patterson, G. and Boyd, M. (1989). AIDS-antiviral sulfolipids from cyanobacteria (blue-green algae). JNCI Journal of the National Cancer Institute, 81(16):1254-1258.

Hirata, T.; Tanaka, M.; Ooike, M.; Tsunomura, T. and Sakaguchi, M. (2000). Antioxidant activities of phycocyanobilin prepared from Spirulina platensis. Journal of Applied Phycology, 12:435-439. 10.1023/ A: 1008175217194

Huheihel, M.; Ishanu, V.; Tal, J. and Arad, S. M. (2002). Activity of Porphyridium sp. polysaccharide against herpes simplex viruses in vitro and in vivo. Journal of Biochemical and Biophysical Methods, 50(2-3):189-200. doi: $10.1016 / \mathrm{s} 0165-022 \times(01) 00186-5$.

Huleihel, M.; Ishanu, V.; Tal, J. and Arad, S. (2001). Antiviral effect of red microalgal polysaccharides on herpes simplex and Varicella zoster viruses. Journal of Applied Phycology, 13(2):127-134.

Huskens, D. and Schols, D. (2012). Algal lectins as potential HIV microbicide candidates. Marine Drugs, 10(12):1476-1497.

Intan, D.; Charlotte, F.; Claire, H.; Nathalie, B. and Jean-Luc, M. (2018). Anticancer, antiviral, antibacterial, and antifungal oroperties in microalgae. ira A. levine; Joël Fleurence. Microalgae in Health and Disease Prevention, Elsevier, pp:235-261

Ishag, H.Z.; Li, C.; Huang, L.; Sun, M.X.; Wang, F.; Ni, B.; Malik, T.; Chen, P.Y. and Mao, X. (2013). Griffithsin inhibits Japanese encephalitis virus infection in vitro and in vivo. Archives of Virology, 158:349-358. 10.1007/s00705-012-1489-2

Jha, R. K. and Zi-rong, X. (2004). "Biomedical compounds frommarine organisms," Marine Drugs, 2(3):123-146.

Jones, C.S.; Luong, T.; Hannon, M.; Tran, M.; Gregory, J.A.; Shen, Z.; Briggs, S.P. and Mayfield, S.P. (2012). Heterologous expression of the C-terminal antigenic domain of the malaria vaccine candidate Pfs $48 / 45$ in the green algae Chlamydomonas reinhardtii. Applied Microbiology and Biotechnology, 97:1987-1995.

Kamat, S.; Wahidulla, S.; D'Souza, L.; Naik, C.; Ambiye, V.; Bhakuni, D.; Goel, A.; Garg, H. and Srimal, R. (1992). Bioactivity of marine organisms. VI. antiviral evaluation of marine algal extracts from the Indian coast. Botanica Marina, 35(2):34-67. https://doi.org/10.1515/ botm.1992.35.2.161

Kwon, J. H.; Lee, D. H.; Swayne, D. E.; Noh, J. Y.; Yuk, S. S.; Erdene-Ochir, T. O.; Hong, W. T.; Jeong, J. H.; Jeong, S.; Gwon, G. B.; Lee, S.; and Song, C. S. (2017). Reassortant clade 2.3.4.4 avian influenza A (H5N6) virus in a wild mandarin duck, South Korea, 2016. Emerging Infectious Diseases, 23(5):822-826. https://doi.org/10.3201/eid2305.161905

Lazarus, J. V.; Sperle, I.; Maticic, M. and Wiessing, L. (2014). “A systematic review of Hepatitis $\mathrm{C}$ virus treatment uptake among people who inject drugs in the European Region," BMC Infectious Diseases, 14(6):S16-S20.

Lee, J.; Koizumi, S.; Hayashi, K. and Hayashi, T. (2010). Structure of rhamnansulfate from the green alga Monostroma nitidum and its anti-herpetic effect. Carbohydrate Polymers, 81(3):572-577.

Levendosky, K.; Mizenina, O.; Martinelli, E.; Jean-Pierre, N.; Kizima, L.; Rodriguez, A.; Kleinbeck, K.; Bonnaire, T.; Robbiani, M.; Zydowsky, T. M.; O'Keefe, B. R. and Fernández-Romero, J. A. (2015). Griffithsin and carrageenan combination to target herpes simplex virus 2 and human papillomavirus. Antimicrobial Agents and Chemotherapy, 59(12), 7290-7298. https://doi.org/10.1128/AAC.01816-15

Li, B.; Lu, F.; Wei, X. and Zhao, R. (2008). Fucoidan: Structure and bioactivity. Molecules, 13(8):1671-1695.

Li, G. and De Clercq, E. (2020). Therapeutic options for the 2019 novel coronavirus (2019-nCoV). Nature Reviews Drug Discovery, 19: 149-150.10.1038/d41573-020-00016-0

Li, X.; Qian, H.; Miyamoto, F.; Naito, T.; Kawaji, K.; Kajiwara, K.; Hattori, T.; Matsuoka, M.; Watanabe, K.; Oishi, S.; Fujii, N. and Kodama, E. N. (2012). A simple, rapid, and sensitive system for the evaluation of antiviral drugs in rats. Biochemical and Biophysical Research Communications, 424(2):257-261.

Liu, C.; Zhou, Q.; Li, Y.; Garner, L.; Watkins, S.; Carter, L.; Smoot, J.; Gregg,A.; Daniels, A.; Jervey, S. and Albaiu D (2020). Research and development on therapeutic agents and vaccines for COVID-19 and related human coronavirus diseases. ACS Central Science, 6(3):315-331.

Loutfy M. S.; Wu, S. and Butler, M. (2011). Review of dengue virus and the development of a vaccine. Biotechnology Advances, 29(2):239247.

Loutfy, M. R.; Wu, W.; Letchumanan, M.; Bondy, L.; Antoniou, T.; Margolese, S.; Zhang, Y.; Rueda, S.; McGee, F.; Peck, R.; Binder, L.; Allard, P.; Rourke, S.B. and Rochon P.A. (2013). Systematic review of HIV transmission between heterosexual serodiscordant couples where the HIVpositive partner is fully suppressed on antiretroviral therapy. PLoS ONE, 8(2):e557-560.

Lusvarghi, S.; Bewley, C. A. and O'keefe, B. R. (2016). Griffithsin: An antiviral lectin with outstanding therapeutic potential. Viruses, 8:296. $10.3390 / \mathrm{v} 8100296$

Mayer, A. and Hamann, M. (2005). Marine pharmacology in 2001-2002: Marine compounds with anthelmintic, antibacterial, anticoagulant, antidiabetic, antifungal, anti-inflammatory, antimalarial, antiplatelet, antiprotozoal, antituberculosis, and antiviral activities; affecting the cardiovascular, immune and nervous systems and other miscellaneous mechanisms of action. Comparative Biochemistry and Physiology Part C: Toxicology and Pharmacology, 140(3-4):265-286.

McCarty, M.F. (2007). Clinical potential of Spirulina as a source of phycocyanobilin. Journal of Medicinal Food, 10:566-570. 10.1089/jmf.2007.621

Mehrotra, N. (2020). Medicinal plants, aromatic herbs and spices as potent immunity defenders: Antiviral (COVID-19) perspectives. Ann. Phytomed., 9(2):30-49.doi.org/10.21276/ap.2020.9.2.4 
Mendes, A.F.; Caramona, M.; Carvalho, A. and Lopes, M. (2003). Hydrogen peroxide mediates interleukin-1 $\beta$-induced AP-1 activation in articular chondrocytes: Implications for the regulation of iNOS expression. Cell Biology and Toxicology, 19(4):203-214.

Merin, D.; Prakash, S. and Valentin, B. (2010). Antibacterial screening of silver nanoparticles synthesized by marine micro algae. Asian Pacific Journal of Tropical Medicine, 3:797-799.10.1016/S19957645(10)60191-5.

Meuleman, P.; Albecka, A.; Belouzard, S.; Vercauteren, K.; Verhoye, L.; Wychowski, C.; Leroux-Roels, G.; Palmer, K. E. and Dubuisson, J. (2011). Griffithsin has antiviral activity against hepatitis C virus. Antimicrobial Agents and Chemotherapy, 55(11):5159-5167. https://doi.org/ 10.1128/AAC.00633-11

Millet, J. K.; Séron, K.; Labitt, R. N.; Danneels, A.; Palmer, K. E.; Whittaker, G. R.; Dubuisson, J. and Belouzard, S. (2016). Middle East respiratory syndrome coronavirus infection is inhibited by griffithsin. Antiviral Research, 133:1-8. doi:10.1016/j.antiviral.2016.07.011.

Moghadamtousi. S.Z.; Kadir, H.A.; Hassandarvish, P.; Tajik, H.; Abubakar, S. and Zandi K. (2014). A review on antibacterial, antiviral, and antifungal activity of curcumin. Bio. Med. Research International, 2014: 186864. doi:10.1155/2014/186864

Mori, T.; O'keefe, B. R.; Sowder, R. C.; Bringans, S.; Gardella, R.; Berg, S.; Cochran, P.; Turpin, J.A.; Buckheit, R.W. Jr.; McMahon, J.B. and Boyd, M.R. (2004). Isolation and characterization of griffithsin, a novel HIVinactivating protein, from the red alga Griffithsia sp. Journal of Biological Chemistry, 280:9345-9353

Munro, M. H.; Luibrand, R. T. and Blunt, J. W. (1987). The search for antiviral and anticancer compounds from marine organisms. Bioorganic Marine Chemistry, 1:93-176.

Murrell, S.; Wu, S.C. and Butler, M. (2011). "Review of dengue virus and the development of a vaccine," Biotechnology Advances, 29(2):239247.

Naesens, L. and Clercq, E. D. (2001). Recent developments in herpesvirus therapy. Herpes: The Journal of the IHMF, 8(1):12-16.

Nikhra, V. (2020). The Trans-zoonotic virome interface: Measures to balance, control and treat epidemics. New Delhi: Annals of Biomedical Engineering; Springer.

Nixon, B.; Stefanidou, M.; Mesquita, P. M.; Fakioglu, E.; Segarra, T.; Rohan, L.; Halford, W.; Palmer, K. E.; and Herold, B. C. (2013). Griffithsin protects mice from genital herpes by preventing cell-to-cell spread. Journal of Virology, 87(11):6257-6269. https://doi.org/10.1128/JVI. $00012-13$

Ohta, S.; Ono, F.; Shiomi, Y.; Nakao, T.; Aozasa, O.; Nagate, T.; Kitamura, K.; Yamaguchi, S.; Nishi, M. and Miyata, H. (1998). Anti-herpes simplex virus substances produced by the marine green alga, Dunaliella primolecta. Journal of Applied Phycology, 10(4):349-356.

O'Keefe, B. R.; Giomarelli, B.; Barnard, D. L.; Shenoy, S.R.; Chan, P. K. S.; McMahon, J. B.; Palmer, K.E.; Barnett, B.W.; Meyerholz, D.K.; WohlfordLenane, C.L. and McCray, P.B. Jr. (2010). Broad-spectrum in vitro activity and in vivo efficacy of the antiviral protein griffithsin against emerging viruses of the family coronaviridae. Journal of Virology, 84:2511-2521.10.1128/JVI.02322-09

Paniagua Michel, J.; Olmos Soto, J. and Morales Guerrero, E. (2014). Algal and microbial exopolysaccharides: New insights as biosurfactants and bioemulsifiers. Advances in Food and Nutrition Research, 73:221 57.10.1016/B978-0-12-800268-1.00011-1.
Paul, S. K.; Hanseul, Oh.; Seok-Joon, K.; Weihua, J.; Fuming, Z; Keith, F.; Jung, J.H.; Robert, J. Li. and Jonathan, S.D. (2020). Sulfated polysaccharides effectively inhibit SARS-CoV-2 in vitro. Cellular Discoveries, 6:50. https://doi.org/10.1038/s41421-020-00192-8

Pendyala, B. and Patras, A. (2020). In silico screening of food bioactive compounds to predict potential inhibitors of COVID-19 main protease (Mpro) and RNA-dependent RNA polymerase (RdRp). Chem. Rxiv. [Preprints]. 10.26434/chemrxiv.12051927.v2

Ramakanth, D.; Singh, S.; Maji, P.K.; Lee, Y.S. and Gaikwad, K.K. (2021). Advanced packaging for distribution and storage of COVID-19 vaccines: A review. Environmental Chemistry Letters, 19:35973608. https://doi.org/10.1007/s10311-021-01256-1

Ramakrishnan, R. (2013). Antiviral properties of Cyanobacterium, Spirulina platensis : A review. International Journal of Medicine and Pharmaceutical Science, 3:1-10.

Reichert, M.; Bergmann, S.M.; Hwang, J.; Buchholz, R. and Lindenberger, C. (2017). Antiviral activity of exopolysaccharides from Arthrospira platensis against koi herpesvirus. The Journal of Fish Diseases, 40:1441-1450.

Serkedjieva, J. (2004). Antiviral activity of the red marine alga, Ceramium rubrum. Phytotherapy Research, 18(6):480-483.

Shih, S.; Tsai, K.; Li, Y.; Chueh, C. and Chan, E. (2003). Inhibition of enterovirus 71-induced apoptosis by allophycocyanin isolated from a bluegreen alga, Spirulina platensis. Journal of Medical Virology, 70(1): 119-125.

Singh, S.; Dwivedi, V.; Sanyal, D. and Dasgupta, S. (2020). Therapeutic and nutritional potential of Spirulina in combating COVID-19 infection. AIJR [Preprints]. 10.21467/preprints.49

Sun, Q. L.; Li, Y.; Ni, L. Q.; Li, Y. X.; Cui, Y. S.; Jiang, S. L.; Xie, E.Y.; Du, J.; Deng, F. and Dong, C.X. (2020). Structural characterization and antiviral activity of two fucoidans from the brown algae Sargassum henslowianum. Carbohydrates and Polymers, 229:115487. 10.1016/j.carbpol.2019.115487

Takebe, Y.; Saucedo, C.; Lund, G.; Uenishi, R.; Hase, S.; Tsuchiura, T.; Kneteman, N.; Ramessar, K.; Tyrrell, D.; Shirakura, M.; Wakita, T.; McMahon, J. and O'Keefe, B. (2013). Antiviral lectins from red and blue-green algae show potent in vitro and in vivo activity against hepatitis $\mathrm{C}$ virus. PLoS ONE, 8(5):644-649.

Tiwari, V.; Shukla, S. and Shukla, D. (2009). A sugar binding protein cyanovirin-N blocks herpes simplex virus type-1 entry and cell fusion. Antiviral Research, 84(1):67-75.

Wang, S.; Wang, W.; Hou, L.; Qin, L.; He, M.; Li, W. and Mao. W. (2020). A sulfated glucuronorhamnan from the green seaweed Monostroma nitidum: Characteristics of its structure and antiviral activity. Carbohydrates and Polymers, 227:115280. doi: 10.1016/j.carbpol.2019.115 280 .

Watson, B.A. and Waaland, S. D. (1983). Partial purification and characterization of a glycoprotein cell fusion hormone from Griffithsia pacifica, a red alga. Plant Physiology, 71:327-332. 10.1104/pp.71.2.327

Yasuhara-Bell, J. and Lu, Y. (2010). "Marine compounds and their antiviral activities," Antiviral Research, 86(3):231-240.

Yeo, C.; Kaushal, S., and Yeo, D. (2020). Enteric involvement of coronaviruses: Is faecal-oral transmission of SARS-CoV-2 possible? Lancet Gastroenterology and Hepatology, 5:335-337. 10.1016/ S2468-1253(20)30048-0 
Yim, J.; Kim, S.; Ahn, S.; Lee, C.; Rhie, K. and Lee, H. (2004). Antiviral effects of sulfated exopolysaccharide from the marine microalga Gyrodinium impudicum strain KG03. Marine Biotechnology, 6(1):17-25

Zalah, L.; Huleihel, M.; Manor, E.; Konson, A.; Ford, H.; Marquez, V.; Johns, D. and Agbaria, R. (2002). Metabolic pathways of N- methanocarbathy midine, a novel antiviral agent, in native and herpes simplex virus type 1 infected vero cells. Antiviral Research, 55(1):63-75.

Zheng, L.; Chen, $\mathbf{X}$. and Cheong, K. (2020). Current trends in marine algae polysaccharides: The digestive tract, microbial catabolism, and prebiotic potential. International Journal of Biological Macromolecules, 151:344-354.
Zhou, P.; Yang, X. L.; Wang, X. G.; Hu, B.; Zhang, L.; Zhang, W.; Hao-Rui, S.; Yan, Z.; Bei, L.; Chao-Lin, H.; Hui-Dong, C.; Jing, C,; Yun, L.; Hua, G.; Ren-Di, J.; Mei-Qin, L.; Ying, C. Xu-Rui, S.; Xi, W.; Xiao-Shuang, Z.; Kai, Z.; QuanJiao, C.; Fei, D.; Lin-Lin, L,; Bing, Y.; Fa-Xian, Z.; Yan-Yi, W.; Geng-Fu, X. and Zheng-Li, S. (2020). A pneumonia outbreak associated with a new coronavirus of probable bat origin. Nature, 579:270-273. 10.1038/ s4 1586-020-2012-7

Zumla, A. W.; Chan, J. F.; Azhar, E. I. C.; Hui D. S.; and Yuen, K.Y. (2016). Coronaviruses-drug discovery and therapeutic options. Nature Review Drug Discovery, 15:327-347. 10.1038/nrd.2015.37.

Afroz Alam, Fozia Bibi and Kanishka Porwal (2021). Potential of algae-derived bioactive molecules for cure of SARS-CoV-2. Ann. Phytomed., Volume10, Special Issue2 (COVID-19): S29-S40. http://dx.doi.org/10.54085/ ap.covid19.2021.10.2.4 